\title{
PENGARUH SENAM DIABETES TERHADAP KADAR GULA DARAH PENDERITA DIABETES MELITUS TIPE II
}

\author{
Rukmini Syahleman ${ }^{1}$, Julianus ${ }^{2}$, Ni Wayan Rahayu Ningtyas ${ }^{3}$ \\ ${ }^{1,2,3}$ STIKes Borneo Cendekia Medika, Pangkalan Bun \\ rukminisyahleman@gmail.com
}

\begin{abstract}
ABSTRAK
DM tipe II merupakan dampak dari ketidakseimbangan insulin dalam tubuh akibat obesitas, gaya hidup, dan pola makan. Konsumsi karbohidrat yang berlebih menyebabkan ketidakseimbangan ikatan insulin dan karbohidrat dalam darah (Hudak dan gallo, 2010). Tujuan utama terapi diabetes adalah menormalkan aktivitas insulin dan kadar glukosa darah untuk mengurangi komplikasi yang ditimbulkan akibat Diabetes Melitus. Salah satu model latihan fisik bagi penderita diabetes melitus yang dikembangkan di Indonesia antara lain adalah dengan Senam Diabetes. Desain yang digunakan pada penelitian ini adalah Quasi Experimental Design dengan menggunakan model Non Equivalent Control Grup Desaign. Jumlah sampel 70 orang dengan teknik sampel yaitu total sampling. Pengumpulan data menggunakan observasi sebelum perlakuan dan sesudah perlakuan. Hasil penelitian pengaruh senam diabetes terhadap kadar gula darah penderita diabetes melitus tipe II di Puskesmas Kelurahan Pangkut, Kecamatan Arut Utara, Kabupaten Kotawaringin Barat. Hasil uji statistik dengan menggunakan uji T-Paired didapatkan nilai $\mathrm{p}$ value $=0,000<0,05$, maka $\mathrm{H} 1$ diterima. Kesimpulan ada pengaruh senam diabetes terhadap kadar gula darah penderita diabetes melitus tipe II di Puskesmas Kelurahan Pangkut, Kecamatan Arut Utara, Kabupaten Kotawaringin Barat.
\end{abstract}

Kata Kunci : Senam diabetes melitus, Kadar gula darah

\section{ABSTRACT}

Type II DM is an impact of insulin imbalance in the body due to obesity, lifestyle, and diet. Excessive carbohydrate consumption causes an imbalance of insulin and carbohydrate bonds in the blood (Hudak and Gallo, 2010). The main goal of diabetes therapy is to normalize insulin activity and blood glucose levels to reduce complications caused by Diabetes Mellitus. One model of physical exercise for people with diabetes mellitus developed in Indonesia, among others, is Diabetes Gymnastics. The design used in this study is Quasi Experimental Design by using the Non Equivalent Control Group Desaign model. The number of samples was 70 people with a total sampling technique. Data collection uses observations before treatment and after treatment. The results of the study of the influence of diabetes exercises on blood sugar levels of type II diabetes mellitus in the Pahlawan Village Health Center, Arut Utara District, Kotawaringin Barat Regency. Statistical test results using the T-Paired test obtained p value $=0,000$ $<0.05$, then $\mathrm{Hl}$ is accepted. Conclusion there is the influence of diabetes exercises 
on blood sugar levels of type II diabetes mellitus in the Health Village Kelurahan Pangkut, Arut Utara District, Kotawaringin Barat Regency.

Keywords: Diabetes mellitus, blood sugar levels

\section{PENDAHULUAN}

Diabetes Melitus (DM) merupakan suatu penyakit dari kumpulan gejala yang timbul pada seseorang sebagai akibat peningkatan kadar glukosa darah yang dikarenakan penurunan sekresi insulin yang progresif disebabkan oleh retensi insulin (Soegondo, Soewondo \& Subekti 2011). Menurut American Diabetes Association, DM adalah suatu penyakit metabolik dengan karakteristik kenaikan kadar glukosa dalam darah atau hiperglikemia dan gangguan metabolisme karbohidrat, lemak, dan protein yang disebabkan karena kelainan sekresi insulin, gangguan kerja insulin atau keduanya (ADA, 2012).

DM terjadi ketika pankreas tidak dapat memproduksi insulin yang cukup atau ketika tubuh tidak dapat menggunakan insulin yang telah diproduksi secara efektif. Insulin merupakan hormon yang mengatur kadar gula darah, dimana kadar gula darah yang meningkat sering ditemukan pada DM yang tidak terkontrol. DM yang tidak terkontrol pada waktu yang lama dapat menyebabkan komplikasi baik makrovaskular maupun mikrovaskular (WHO, 2016). DM merupakan salah satu penyakit yang tersembunyi atau sering disebut dengan the silent killer. Beberapa gejala yang sering muncul yaitu seperti mudah lapar, mudah haus dan sering buang air kecil. Gejala yang sering dirasakan oleh pasien ketika pasien sudah terdiagnosa diabetes (ADA, 2012). Seseorang mulai dikatakan menderita diabetes melitus apabila orang tersebut memiliki kadar gula darah puasa $>126 \mathrm{mg} / \mathrm{dl}$ dan pada tes gula darah sewaktu $>200 \mathrm{mg} / \mathrm{dl}$. Tes gula darah sewaktu akan meningkat setelah makan dan akan kembali normal dalam waktu 2 jam (Perkeni, 2011).

DM merupakan penyakit degeneratif yang memerlukan upaya penanganan yang tepat dan serius karena dapat menimbulkan komplikasi seperti meningkatnya risiko penyakit jantung atau stroke, penyebab utama kebutaan, selain itu DM juga merupakan salah satu penyebab utama penyakit gagal ginjal, dan neuropati atau kerusakan sistem saraf di kaki yang meningkatkan kejadian ulkus kaki.

Faktor risiko DM dapat dikelompokan menjadi faktor risiko yang tidak dapat dimodifikasi dan yang dapat dimodifikasi. Faktor risiko yang tidak dapat dimodifikasi antara lain ras dan etnik, umur, jenis kelamin, riwayat keluarga dengan diabetes melitus, riwayat melahirkan bayi dengan berat badan lebih dari 4000 gram, dan riwayat lahir dengan berat dan lahir rendah atau kurang dari 2500 gram. Sedangkan faktor risiko yang dapat dimodifikasi erat kaitannya dengan perilaku hidup yang kurang sehat, yaitu berat badan lebih, obesitas abnormal/sentral, kurangnya aktivitas fisik, hipertensi, diet tidak sehat/tidak seimbang, dan 
riwayat toleransi glukosa terganggu atau gula darah puasa terganggu serta merokok (Kemenkes RI, 2014).

Beberapa jenis DM terjadi karena interaksi yang kompleks dari lingkungan, genetik, dan pola hidup sehari-hari (American Diabetes Association, 2010). Terdapat dua tipe utama penyakit DM. Pada DM tipe I diartikan sebagai insulin dependen atau juvenile / childhood - onset diabetes. DM tipe I ditandai dengan ketidakmampuan tubuh untuk memproduksi insulin. Sehingga pasokan insulin didalam tubuh tidak tercukupi.

DM tipe II diartikan sebagai non insulin dependent atau adult onset diabetes,yang disebabkan penggunaan insulin yang kurang effektif oleh tubuh. DM tipe II merupakan dampak dari ketidakseimbangan insulin dalam tubuh akibat obesitas, gaya hidup, dan pola makan. Konsumsi karbohidrat yang berlebih menyebabkan ketidakseimbangan ikatan insulin dan karbohidrat dalam darah (Hudak dan gallo, 2010).

DM tipe II merupakan penyakit yang beresiko tinggi dari diabetes yang lain dengan 90\% tingkat keparahan (Kemenkes RI, 2014). Pada DM tipe II, tubuh dapat memproduksi insulin namun dalam jumlah yang tidak cukup dimana tubuh tidak dapat memberi respon terhadap efek insulin sehingga menyebabkan penumpukan glukosa dalam darah (IDF, 2013). DM tipe II sebagian besar disebabkan oleh predisposisi genetik yang diiringi dengan faktor lingkungan lain, seperti kelebihan berat badan dan kekurangan aktivitas fisik (WHO, 2015).
Secara global, diperkirakan 422 juta orang dewasa hidup dengan diabetes pada tahun 2014, dibandingkan dengan 108 juta pada tahun 1980. Prevalensi diabetes di dunia (dengan usia yang di standarisasi) telah meningkat hampir dua kali lipat sejak tahun 1980, meningkat dari $4,7 \%$ menjadi $8,5 \%$ pada populasi orang dewasa. Hal ini mencerminkan peningkatan faktor risiko terkait seperti kelebihan berat badan atau obesitas. Selama beberapa dekade terakhir, prevalensi diabetes meningkat lebih cepat di negara berpenghasilan rendah dan menengah daripada di negara berpenghasilan tinggi.

Data organisasi kesehatan dunia WHO (2015), Indonesia menempati urutan ke enam di dunia sebagai negara dengan jumlah penderita DM terbanyak setelah India, Cina, Unisoviet, Jepang dan Brazil. Menurut estimasi International Diabetes Federation, bahwa jumlah penduduk Indonesia usia 20 tahun keatas menderita DM sebanyak 5,6 juta orang pada tahun 2001 dan angka tersebut akan meningkat menjadi 8,2 juta pada tahun 2020. Pada tahun 2014 di Asia Tenggara , terdapat 96 juta orang yang menderita diabetes.

Menurut data BPS Provinsi Kalimantan Tengah pada sensus tahun 2018, mencapai 7.254 orang yang terkena penyakit diabetes, dan merupakan penyakit terbanyak ke 5 di Kalimantan Tengah setelah influenza di urutan pertama. Diketahui meningkatnya penyakit diabetes melitus akibat resiko dari konsumsi makanan, olahraga yang tidak teratur, stress, dan kurangnya penggunaan fasilitas kesehatan 


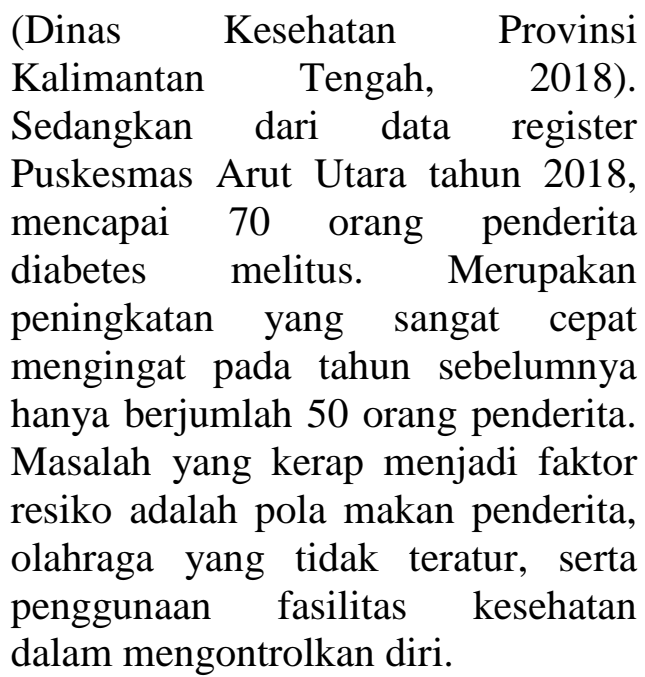
Latihan jasmani merupakan salah satu pilar dalam pengelolaan diabetes mellitus tipe II. Selain untuk menjaga kebugaran juga dapat menurunkan berat badan dan memperpaiki sensitivitas insulin sehingga dapat memperbaiki kendali glukosa darah (Perkumpulan Endokrinologi Indonesia, 2011).

Aktivitas fisik merupakan segala bentuk gerakan yang dapat menyebabkan pembakaran kalori pada tubuh. Selama melakukan aktivitas fisik, otot-otot akan aktif menggunakan glukosa sebagai sumber energi. Sehingga dengan aktivitas fisik yang teratur akan membantu mencegah terbentuknya glukosa dalam darah. Akan tetapi kebanyakan individu tidak mendapatkan aktivitas fisik yang cukup, apalagi dengan banyaknya perkembangan teknologi dan kehidupan modern telah membuat banyaknya bentuk aktivitas fisik biasa pada kehidupan sehari-hari terhapuskan. Salah satu model latihan fisik bagi penderita diabetes melitus yang dikembangkan di Indonesia antara lain adalah dengan Senam Diabetes.

Senam diabetes yang dilakukan sehari-hari secara teratur dapat memperbaiki profil lemak, menurunkan berat badan dan menjaga kebugaran. Selain itu akan meningkatkan sensitivitas insulin sehingga akan menurunkan glukosa darah. Senam diabetes yang dianjurkan antara lain bersifat aerobik. Penggunaan glukosa pada otot yang aktif dalam hal tersebut akan meningkat, akan tetapi tidak disertai dengan peningkatan insulin. Hal tersebut disebabkan oleh meningkatnya kepekaan reseptor insulin diotot pada saat berolahraga. Sinaga dan Hondro (2012), mengatakan bahwa pada penderita Diabetes Melitus Tipe I dan II terdapat adanya pengaruh antara latihan fisik dengan turunnya kadar glukosa darah. Hal ini dibuktikan dengan penurunan kadar glukosa darah rata-rata $60 \%$.

Penelitian lain yang dilakukan oleh Andri Nugraha dengan judul "Kadar Gula Darah Sebelum dan Sesudah Melaksanakan Senam Diabetes Pada Pasien Diabetes Melitus Tipe II". Hasil penelitian didapatkan dari rata-rata kadar gula darah sebelum senam diabetes $164,50 \mathrm{mg} / \mathrm{dl}$ dan sesudah senam diabetes 145,13 mg/dl. Hasil uji statistik memperlihatkan bahwa nillai P-value sebesar 0,0005 yang lebih kecil dari nilai $\alpha(0,05)$. Hal ini memberi informasi untuk menolak H0, sehingga disimpulkan terdapat perbedaan kadar gula darah sebelum dan sesudah senam diabetes. Penelitian diharapkan menjadi tambahan informasi untuk tetap menjadwalkan senam yang sudah rutin dilaksanakan.

Rumusan masalah pada penelitian ini adalah apakah ada 
pengaruh senam diabetes terhadap kadar gula darah penderita diabetes melitus tipe II di Puskesmas Kelurahan Pangkut, Kecamatan Arut Utara, Kabupaten Kotawaringin Barat. Tujuan utama terapi diabetes adalah menormalkan aktivitas insulin dan kadar glukosa darah untuk mengurangi komplikasi yang ditimbulkan akibat Diabetes Melitus. Salah satu model latihan fisik bagi penderita diabetes melitus yang dikembangkan di Indonesia antara lain adalah dengan Senam Diabetes. Manfaat dilakukan penelitian ini adalah Mengetahui pengaruh senam diabetes terhadap kadar gula darah pada penderita diabetes melitus.

\section{METODE PENELITIAN}

Desain yang digunakan pada penelitian ini adalah Quasi Experimental Design dengan menggunakan model Non Equivalent Control Grup Desaign. Sebelum diberi perlakuan, baik kelompok eksperimen dan kelompok kontrol diberi tes yaitu pretest, dengan maksud untuk mengetahui keadaan kelompok sebelum perlakuan. Kemudian setelah diberikan perlakuan, kelompok eksperimen dan kelompok kontrol diberikan test yaitu posttest, untuk mengetahui keadaan kelompok setelah diberikan perlakuan senam diabetes.

\begin{tabular}{lcr}
\multicolumn{1}{c}{ Tempat } & dan & Waktu \\
Penelitian, & penelitian & ini \\
dilaksanakan di Puskesmas & Arut
\end{tabular} Utara Kelurahan Pangkut pada tanggal 01 November-30 November 2019. Populasi dalam penelitian ini adalah Semua penderita Diabetes Melitus Tipe II di Puskesmas Arut Utara dengan jumlah 70. Teknik pengambilan sampel pada penelitian ini dilakukan dengan cara Total Sampling. Dimana jumlah sampel sama dengan jumlah populasi, alasan mengambil teknik ini berdasarkan jumlah populasi yang kurang dari 100, sehingga jumlah sampel dalam penelitian ini sebanyak 70 orang.

Pengumpulan Data Data yang dikumpulkan merupakan data primer. Alat pengumpulan data yang digunakan adalah lembar observasi Assessment Tool (CBAT) yang telah dimodifikasi dan diuji validitas untuk mengukur perilaku caring, dan Hamilton Rating Scale for Anxiety (HRS-A) untuk mengukur tingkat kecemasan keluarga.

Analisa Univariat dilakukan untuk dapat menggambarkan dari masing-masing variabel, baik variabel bebas dan variabel terikat dan karakteristik responden. Variabel dalam penelitian ini yaitu variabel bebas/independen adalah senam diabetes dan variabel terikat/dependen adalah kadar gula darah. Analisis bivariat dalam penelitian menggunakan Metode Analisa Statistik Uji T Paired dengan mengunakan bantuan software SPSS dengan tingkat signifikan $p>0,05$.

\section{HASIL DAN PEMBAHASAN}

Analisa Univariat

Data umum menyajikan data seperti umur, jenis kelamin, pendidikan, dan pekerjaan.

1) Umur

Karakteristik umur penderita Diabetes Melitus Tipe II di Kelurahan Pangkut yaitu :

Tabel 5.1 Distribusi frekuensi 
berdasarkan umur penderita Diabetes Melitus Tipe II di Kelurahan Pangkut pada tahun $2019(n=70)$.

Hasil dari tabel 5.1 bahwa sebagian besar penderita berusia 41-50 tahun dengan jumlah 31 penderita. Menurut peneliti faktor usia mempengaruhi karena adanya penurunan fisiologis pada tubuh, menyebabkan penurunan fungsi pangkreas untuk memproduksi insulin maupun untuk menyerap gula darah.

\section{2) Jenis Kelamin}

Karakteristik jenis kelamin penderita Diabetes melitus Tipe II di Kelurahan Pangkut yaitu :

Tabel 5.2 Distribusi frekuensi berdasarkan jenis kelamin penderita Diabetes Melitus Tipe II di Kelurahan Pangkut tahun $2019(\mathrm{n}=70)$.

\begin{tabular}{lll}
\hline $\begin{array}{l}\text { Jenis } \\
\text { kelamin }\end{array}$ & Jumlah & Presentase \\
\hline Laki-Laki & 23 & $32 \%$ \\
\hline Perempuan & 47 & $67 \%$ \\
\hline Total & 70 & $100 \%$ \\
\hline
\end{tabular}

Hasil penelitian dari tabel 5.2 menyatakan bahwa dari jenis kelamin penderita yang mengalami diabetes melitus berjenis kelamin perempuan dengan jumlah 47 penderita $(67 \%)$. Menurut peneliti faktor utama penurunan hormon esterogen saat menopause adalah hal utama perempuan berisiko tinggi terkena Diabetes Melitus dimana hormone esterogen berfungsi sebagai pengatur dalam meningkatkan respon insulin di dalam darah.
3) Pendidikan

Karakteristik pendidikan penderita Diabetes melitus tipe II di Kelurahan

\begin{tabular}{ccc}
\hline Umur & Jumlah & Presentase \\
\hline $31-40$ & 20 & $28 \%$ \\
\hline $41-50$ & 31 & $44 \%$ \\
\hline $51-60$ & 13 & $18 \%$ \\
\hline $61-70$ & 6 & $8 \%$ \\
\hline Total & 70 & $100 \%$ \\
\hline Pangkut yaitu: &
\end{tabular}

Pangkut yaitu :

Tabel 5.3 Distribusi frekuensi pendidikan penderita Diabetes Melitus Tipe II di Kelurahan Pangkut tahun 2019 (n=70).

\begin{tabular}{lll}
\hline Pendidikan & Jumlah & Presentase \\
\hline SD & 22 & $31 \%$ \\
\hline SMP & 23 & $32 \%$ \\
\hline SMA & 24 & $34 \%$ \\
\hline $\begin{array}{l}\text { Perguruan } \\
\text { Tinggi }\end{array}$ & 1 & $1 \%$ \\
\hline Total & 70 & $100 \%$ \\
\hline
\end{tabular}

Hasil penelitian dari tabel 5.3 menyatakan bahwa sebagian besar pendidikan penderita diabetes melitus berpendidikan SMA dengan jumlah 24 penderita (34\%). Dengan berpendidikan yang lebih tinggi orang akan lebih banyak memiliki pengetahuan tentang penyakit dan akan lebih memiliki kesadaran untuk menjaga kesehetannya.

Pekerjaan Jumlah Presentase 


\begin{tabular}{|c|c|c|c|c|}
\hline \multicolumn{2}{|c|}{$\begin{array}{l}\text { Tidak } \\
\text { Bekerja }\end{array}$} & 1 & \multicolumn{2}{|l|}{$1 \%$} \\
\hline \multicolumn{2}{|l|}{ IRT } & 35 & \multicolumn{2}{|l|}{$50 \%$} \\
\hline \multicolumn{2}{|c|}{ Buruh/Petani } & 23 & \multicolumn{2}{|l|}{$32 \%$} \\
\hline \multicolumn{2}{|c|}{ Wirasawasta } & 9 & \multicolumn{2}{|l|}{$12 \%$} \\
\hline $\begin{array}{l}\text { dar } \\
\text { la } \\
\text { rah }\end{array}$ & Mean & $\begin{array}{l}\text { Standar } \\
\text { Deviasi }\end{array}$ & $\begin{array}{l}\text { Mini } \\
\text { mum }\end{array}$ & $\begin{array}{l}\text { Maxi } \\
\text { mum }\end{array}$ \\
\hline pelum & 256.77 & 85.197 & 115 & 434 \\
\hline udah & 236.20 & 78.507 & 110 & 415 \\
\hline PNS & & 2 & $2 \%$ & \\
\hline Total & & 70 & $100 \%$ & \\
\hline
\end{tabular}

\section{4) Pekerjaan}

Karakteristik pekerjaan penderita Diabetes Melitus Tipe II di Kelurahan Pangkut yaitu :

Tabel 5.4 Distribusi frekuensi pekerjaan penderita Diabetes melitus Tipe II di Kelurahan Pangkut tahun 2019 ( $\mathrm{n}=70)$.

\section{Analisa Bivariat}

Data khusus akan menyajikan hasil tabulasi Pengaruh Senam Diabetes Terhadap Kadar Gula Darah Penderita Diabetes Melitus Tipe II.

1. Uji normalitas data hasil penelitan kadar gula darah penderita Diabetes Melitus Tipe II di Kelurahan Pangkut yaitu :

Tabel 5.5 Uji normalitas Kolmogorovsmirnov.

\begin{tabular}{ccc}
\hline & Statistik & sig \\
\hline Sebelum & .113 & .200 \\
\hline
\end{tabular}

$\begin{array}{lll}\text { Sesudah } & .110 \quad .200\end{array}$

Pada tabel 5.5 menunjukan hasil uji normalitas dengan menggunakan uji Kolmogorov-smirnov dimana hasil dinyatakan normal dengan didapat nilai Sig sebelum yaitu Sig- 0,200 dan sesudah yaitu Sig- 0,200. Dinyatakan data berdistribusi normal karena lebih besar dari 0,05 .

2. Karakteristik kelompok intervensi dengan Senam Diabetes di Kelurahan Pangkut yaitu :

Tabel 5.6 Distribusi frekuensi kelompok intervensi dengan Senam Diabetes di Kelurahan Pangkut.

Pada tabel 5.6 Menunjukan bahwa hasil penelitian kadar gula darah sebelum dan sesudah senam diabetes pada penderita Diabetes Melitus Tipe II dengan distribusi rata - rata nilai yaitu sebelum senam diabetes $256.77 \mathrm{mg} / \mathrm{dl}$ dan sesudah senam diabetes $236.20 \mathrm{mg} / \mathrm{dl}$ dengan nilai kadar gula sebelum senam diabetes terendah $115 \mathrm{mg} / \mathrm{dl}$ dan tertinggi $434 \mathrm{mg} / \mathrm{dl}$, kadar gula sesudah senam diabetes terendah $110 \mathrm{mg} / \mathrm{dl}$ dan tertinggi $415 \mathrm{mg} / \mathrm{dl}$.

3. Analisis pengaruh senam diabetes terhadap kadar gula darah penderita Diabetes Melitus Tipe II.

Tabel 5.7 Hasil analisis pengaruh senam diabetes sebelum dan sesudah senam diabetes terhadap kadar gula darah penderita Diabetes Melitus Tipe II di Kelurahan Pangkut.

\begin{tabular}{|c|c|}
\hline $\begin{array}{ll}\text { Kadar } \\
\text { Gula } \\
\text { Darah }\end{array}$ & $\begin{array}{l}\text { Standar } \\
\text { Deviasi }\end{array}$ \\
\hline Sebelum 256.77 & 85.197 \\
\hline Sesudah 236.20 & 78.507 \\
\hline $\begin{array}{l}\text { Pada tabel } \\
\text { penelitian bahy } \\
\text { darah sebelum } \\
256.77 \mathrm{mg} / \mathrm{dl} \\
\text { 85.197. Pada res }\end{array}$ & $\begin{array}{l}5.7 \text { Didapatkan hasil } \\
\text { wa rata-rata kadar gula } \\
\text { senam diabetes adalah } \\
\text { dengan standar deviasi } \\
\text { esponden yang sama rata - }\end{array}$ \\
\hline
\end{tabular}


rata kadar gula darah sesudah senam diabetes adalah $236.20 \mathrm{mg} / \mathrm{dl}$ dengan standar deviasi 78.507. Hasil uji statistik dengan menggunakan uji T-Paired didapatkan nilai $\mathrm{p}$ value $=0,000$ maka Kriteria pengujian adalah bila $\mathrm{p}$ value $\leq$ alpha maka dengan derajat kepercayaan $5 \%(0,05)$ maka disimpulkan bahwa terdapat perbedaan kadar gula darah penderita Diabetes Melitus Tipe II yang signifikan antara sebelum senam diabetes dan sesudah senam diabetes. Ini menunjukan ada pengaruh senam diabetes melitus terhadap perubahan kadar gula darah pada penderita diabetes melitus tipe II.

\section{KESIMPULAN DAN SARAN}

Terdapat pengaruh antara senam diabetes terhadap kadar gula darah penderita Diabetes Melitus Tipe II, dengan menggunakan uji $T$ Paired didapatkan nilai $p$ value $=$ 0,000 . Hasil penelitian ini dapat dijadikan masukan untuk penelitian selanjutnya dengan menambahkan jam istirahat pada saat setelah melakukan senam diabetes dan sebelum dilakukan pemeriksaan kadar gula darah dan peneliti menyarankan sebaiknya dispesifikan untuk kadar gula yang akan diteliti.

\section{DAFTAR PUSTAKA}

ADA. 2014. Diagnosis And Classification Of diabetes mellitus. Diabetes Care, Volume 37.

ADA. 2012. Medical advice for people with diabetes in emergency situations. American Diabetes Association Journal.

Anani. 2012. Hubungan antara perilaku pengendalian Diabetes dan Kadar Gula Darah Pasien.

Bagus. 2013. Pengaruh Konseling pada Keluarga Terhadap
Pengetahuan Keluarga tentang Pola Diet Pasien DM di Puskesmas Mojo agung. Skripsi.

BPS. 2018. https://kalteng.bps.go.id/ jumlah kasus 10 penyakit terbanyak di provinsi kalimantan tengah 2018. Diakses tanggal 28 juli 2019.

Damayanti, Deni. 2013. Sembuh total diabetes, asam urat, hipertensi tanpa obat. Yogakarta : Pinang Merah.

Damayanti, Santi. 2015. Diabetes Mellitus dan Penatalaksanaan Keperawatan. Yogyakarta : Nuha Medika.

Darwin, P. 2013. Menikmati Gula Tanpa Rasa Takut. Yogyakarta : Sinar Ilmu.

Dorland, W. A. 2010. Kamus Kedokteran Dorland Ed.31 (Alih Bahasa : Albertus Agung Mahode). Jakarta : EGC.

Grant J.F, Hicks N, Taylor A.W, Chittleborough C.R, Phillips P.J. 2009. Gender-Specific Epidemiology of Diabetes : a Representative Cross-Sectional Study. International Journal for Equity in Health. (http://www.equityhealthj.com/conte nt//1/6 diakses pada 5 Januari 2020). Hudak dan Gallo. 2010. Keperawatan Kritis Edisi 6. Jakarta: EGC.

IDF. 2017. Diabetes. Atlas Seventh Edition : International Diabetes Federation. 
Ilyas, E. I. ,2011. Penatalaksanaan Diabetes Melitus Terpadu bagi dokter maupun edukator diabetes. Jakarta : Fakultas Kedokteran Universitas Indonesia.

Irawan. 2010. Prevalensi dan Faktor Risiko Kejadian Diabetes Melitus Tipe 2 di Daerah Urban Indonesia. Universitas Indonesia.

Nasir. 2011. Buku Ajar Metodologi Kesehatan. Yogyakarta : Nuha Medika.

Novitasari, retno. 2012. Diabetes Mellitus dilengkapi dengan senam DM. Yogyakarta: Nuha Medika.

Notoadmodjo, Soekidjo. 2012. Metodelogi Penelitian Kesehatan. Jakarta : Rineka Cipta.

Nursalam. 2015. Metodologi Penelitian Ilmu Keperawatan. Jakarta : Salemba Medika.

Perkenni. 2015. Konsensus pengelolaan diabetes melitus tipe 2 di indonesia " PB PERKENNI.

Rondhianto. 2011. Pengaruh Diabetes Self Management Education Dalam Discharge Planning Behavior Pasie Diabetes Mellitus Tipe 2. Thesis FKP. Ubnair . Surabaya : FKP Unair.

Sinaga, J, \& Hondro, E. 2012. Pengaruh Senam Diabetes Melitus Terhadap Kadar Glukosa Darah Pada Penderita Diabetes Melitus Tipe 2 Di Wilayah Kerja Puskesmas Darusalam Medan 2011. Jurnal Mutiara Ners.
Soegondo, S. 2011. Diagnosis dan Klasifikasi Diabetes Melitus. Penatalaksanaan Diabetes Melitus Terpadu Bagi Dokter Maupun Edukator Diabetes. Jakarta : Fakultas Kedokteran Universitas Indonesia.

Sudoyo, A. 2010. Buku Ajar Ilmu Penyakit Dalam Edisi 3. Jakarta : FKUI.

Soenardi, Tuti dan Tim Yayasan Gizi Kuliner. 2014. Mengangkat Gizi dan Kuliner Makanan Rumah Sakit. Jakarta: PT. Gramedia Pustaka Utama.

Tarwoto, dkk. 2012. Keperawatan Medikal Bedah Ganguan Sistem Endokrin. Jakarta : Trans Info Media.

WHO. 2016. Global Report On Diabetes. France : World Health Organization. 